University of Nebraska - Lincoln

DigitalCommons@University of Nebraska - Lincoln

Publications, Agencies and Staff of the U.S.

Department of Commerce

U.S. Department of Commerce

2004

\title{
Life-History Divergence In Chinook Salmon: Historic Contingency And Parallel Evolution
}

Robin Waples

NOAA, robin.waples@noaa.gov

David J. Teel

Northwest Fisheries Science Center, david.teel@noaa.gov

James M. Myers

Northwest Fisheries Science Center, jim.myers@noaa.gov

Anne R. Marhsall

Washington Department of Fish and Wildlife, annermarshall22@gmail.com

Follow this and additional works at: https://digitalcommons.unl.edu/usdeptcommercepub

Waples, Robin; Teel, David J.; Myers, James M.; and Marhsall, Anne R., "Life-History Divergence In Chinook Salmon: Historic Contingency And Parallel Evolution" (2004). Publications, Agencies and Staff of the U.S. Department of Commerce. 454.

https://digitalcommons.unl.edu/usdeptcommercepub/454

This Article is brought to you for free and open access by the U.S. Department of Commerce at DigitalCommons@University of Nebraska - Lincoln. It has been accepted for inclusion in Publications, Agencies and Staff of the U.S. Department of Commerce by an authorized administrator of DigitalCommons@University of Nebraska - Lincoln. 


\title{
LIFE-HISTORY DIVERGENCE IN CHINOOK SALMON: HISTORIC CONTINGENCY AND PARALLEL EVOLUTION
}

\author{
Robin S. Waples, ${ }^{1,2}$ David J. Teel, ${ }^{1}$ James M. Myers, ${ }^{1}$ and Anne R. Marshall ${ }^{3}$ \\ ${ }^{1}$ National Marine Fisheries Service, Northwest Fisheries Science Center, 2725 Montlake Boulevard East, \\ Seattle, Washington 98112 \\ ${ }^{2}$ E-mail: robin.waples@noaa.gov \\ ${ }^{3}$ Washington Department of Fish and Wildlife, 600 Capitol Way North, Olympia, Washington 98501
}

\begin{abstract}
By jointly considering patterns of genetic and life-history diversity in over 100 populations of Chinook salmon from California to British Columbia, we demonstrate the importance of two different mechanisms for lifehistory evolution. Mapping adult run timing (the life-history trait most commonly used to characterize salmon populations) onto a tree based on the genetic data shows that the same run-time phenotypes exist in many different genetic lineages. In a hierarchical gene diversity analysis, differences among major geographic and ecological provinces explained the majority $(62 \%)$ of the overall $G_{\mathrm{ST}}$, whereas run-time differences explained only $10 \%$. Collectively, these results indicate that run-timing diversity has developed independently by a process of parallel evolution in many different coastal areas. However, genetic differences between coastal populations with different run timing from the same basin are very modest $\left(G_{\mathrm{ST}}<0.02\right)$, indicating that evolutionary divergence of this trait linked to reproductive isolation has not led to parallel speciation, probably because of ongoing gene flow. A strikingly different pattern is seen in the interior Columbia River Basin, where run timing and other correlated life-history traits map cleanly onto two divergent genetic lineages $\left(G_{\mathrm{ST}} \sim 0.15\right)$, indicating that some patterns of life-history diversity have a much older origin. Indeed, genetic data indicate that in the interior Columbia Basin, the two divergent lineages behave essentially as separate biological species, showing little evidence of genetic contact in spite of the fact that they comigrate through large areas of the river and ocean and in some locations spawn in nearly adjacent areas.
\end{abstract}

Key words. - Allozymes, gene diversity analysis, life-history evolution, Pacific salmon, parallel speciation, run timing.

Received June 2, 2003. Accepted September 4, 2003.

The question of how rapidly and by what mechanisms adaptive differences arise among populations is of central interest to both evolutionary biologists and conservation biologists. Evidence is accumulating that evolution can occur at a rate high enough to be amenable to experimental observation within the lifetime of humans (Thompson 1998; Hendry and Kinnison 1999; Reznick and Ghalambor 2001). In addition, a number of recent studies have demonstrated the importance of parallel evolution, or repeated evolution of ecologically equivalent traits within a taxon (Reznick et al. 1996; Pigeon et al. 1997; Rundle et al. 2000; Johannesson 2001; Johnson 2001). Both types of studies raise questions about the importance of conserving existing life-history diversity and the likelihood that traits, once lost, will evolve once again-questions that are increasingly relevant to understanding the consequences of current rates of decline in biodiversity (Bernatchez 1995; Pimm and Raven 2000; Myers and Knoll 2001).

Understanding the evolution of life-history diversity in salmon is particularly challenging, both because of the enormous complexity in life-history traits expressed by these species (Groot and Margolis 1991; Waples et al. 2001), and because of the conservation crisis faced by both Pacific salmon (Oncorhynchus spp.) and Atlantic salmon (Salmo salar) populations throughout much of their natural range (Nehlsen et al. 1991; National Research Council 1996; Parrish et al. 1998). Consideration of existing life-history diversity in $\mathrm{Pa}$ cific salmon presents an evolutionary conundrum (Allendorf and Waples 1996). One the one hand, the strong homing fidelity and considerable habitat diversity across the geographic range of the species provides ample opportunity for local adaptation, and numerous empirical examples have demonstrated that such adaptations can occur on small geographic scales (Ricker 1972; Taylor 1991). The failure of the vast majority of stock transfers of Pacific salmon to produce self-sustaining populations within the historic range of the species (Withler 1982; Wood 1995) testifies to the general lack of ecological exchangeability (Crandall et al. 2000) of populations. On the other hand, in some areas a great deal of life-history diversity has evolved relatively recently. For example, almost all of British Columbia was covered with ice in the last stage of the Wisconsin glaciation (McPhail and Lindsey 1986), so diversity among salmon populations there has developed through a combination of recolonization from different lineages and evolution in situ within the last 10,000 years. Pacific salmon transplanted to novel environments (e.g., New Zealand and the North American Great Lakes) have evolved variation in life-history traits over much shorter time frames (Kwain and Thomas 1984; Kinnison et al. 1998; Quinn et al. 2000). Recently, it has been proposed that adaptive differences in morphology and life-history traits of sockeye salmon (O. nerka) can also evolve rapidly within the historic range of the species, although this issue remains controversial (Hendry et al. 2000; Gustafson et al. 2001).

Collectively, these results emphasize to both evolutionary and conservation biologists the importance of understanding the tempo and mode of life-history evolution in salmon. Three different processes might be involved: (1) phenotypic plasticity, or the expression of different phenotypes from the same genotype under different environmental conditions; (2) parallel evolution; and (3) historical contingency, including more ancient divergence due to rare or unique evolutionary events. Each of these processes has been shown to be important in salmon. Hard and Hershberger (1995) found that 
all studies that have used an adequate experimental design have found a genetic component to observed life-history variation in Pacific salmon. Nevertheless, most heritabilities for life-history traits in anadromous salmonids are only moderate in size (typically $0.1-0.5$, similar to values found in a wide range of taxa; Roff 1992), indicating a strong environmental component as well. Several authors (e.g., Schluter and Nagel 1995; Bernatchez et al. 1996; Taylor et al. 1996) have described parallel evolution of life-history traits in salmonids and other fishes, while Healey (1983, 1991), McPhail and Lindsey (1986), and Taylor (1990) have argued for the importance of evolution in different glacial refugia in shaping the present day diversity in Pacific salmon.

In this study we jointly consider two extensive and complementary datasets to examine the evolution of life history in Chinook salmon (O. tshawytscha). Data for juvenile and adult life-history traits were collected from more than 100 populations from California, Oregon, Washington, Idaho, and British Columbia, and these data were evaluated in the context of molecular genetic data taken from the same populations. Ordination techniques and nested gene diversity analyses were used to map the life-history traits onto the genetic structure of the populations, thus providing insight into the evolutionary processes that have led to current patterns of diversity. We tested the following expectation: if life-history evolution is a rare or unique event in Chinook salmon, we would expect to find specific traits confined to a single genetic lineage; in contrast, if parallel evolution of life history has been common, we would expect to find the same traits replicated across many genetic lineages (Fig. 1). We also used the genetic and life-history dataset to test Healey's (1983, 1991) hypothesis of two races of Chinook salmon, which he referred to as stream-type (because of their strong dependence on a full year of stream residence before smolting) and oceantype (because they migrate to sea as subyearlings). According to this hypothesis, the two lineages occupied separate glacial refugia, with coastal ocean-type populations persisting in the Pacific and Columbia/Snake refugium to the south and the stream-type populations emerging from the Bering refugium to the north to reinvading the interior Columbia and Fraser Basins following retreat of the glaciers about 13,000 years ago (McPhail and Lindsey 1986). If this hypothesis is true, we would expect to find populations with stream-type lifehistory traits in one genetic lineage and those with oceantype traits in another. Finally, we used the magnitude of genetic differences among populations with different lifehistory traits to roughly estimate the time periods over which life-history evolution can be expected to occur in this species.

\section{Materials And Methods}

\section{Geographic Scope}

Populations were grouped into a number of geographic provinces (Fig. 2) based on geography and major ecological features of the habitat. We used the geographic provinces described by Waples et al. (2001), with some modification to accommodate the slightly larger geographic scope of this study.
Single evolutionary event
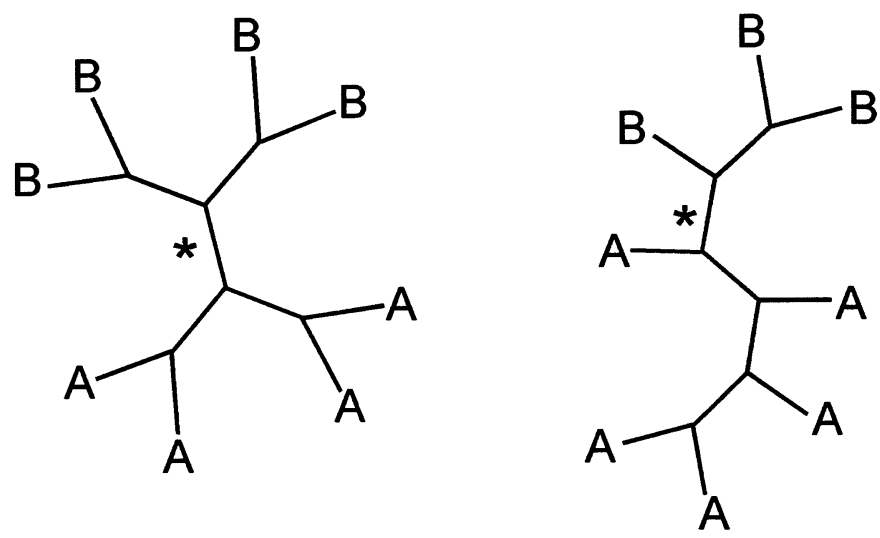

Parallel evolution
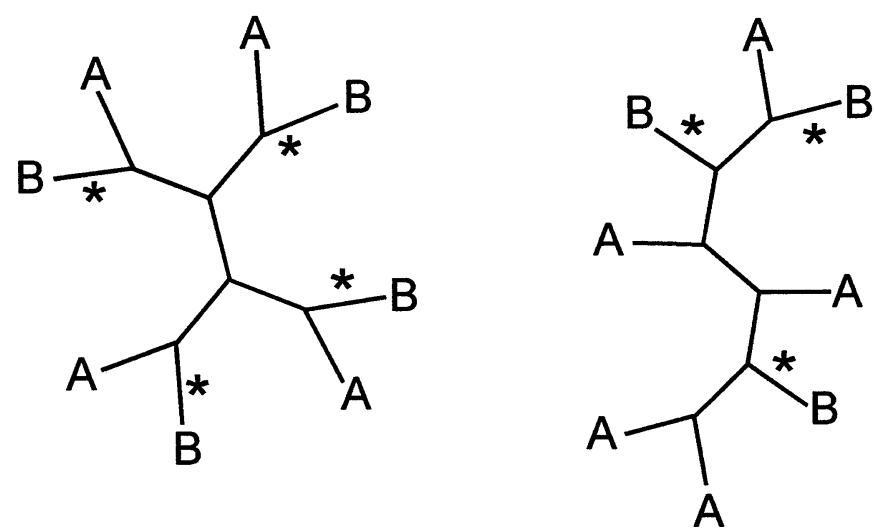

FIG. 1. Two generalized patterns of evolution of life-history traits. An asterisk denotes an evolutionary change. Top panel: The pattern of genetic/life-history relationships can be explained by a single episode in which trait B evolved from trait A (or vice versa). Bottom panel: A minimum of four (left) or three (right) parallel evolutionary changes is required to explain the observed pattern of relationships.

\section{Genetic Data}

Genetic data used in this study were drawn from a coastwide dataset collected by laboratories that have cooperated since the early 1980s to standardize the allozyme analysis of Chinook and other salmon species (Shaklee and Phelps 1990). Laboratory procedures used for protein electrophoresis were described by Aebersold et al. (1987) and Waples et al. (1993). The present study used data from 118 populations (see Appendix 1) scored for the same suite of 32 polymorphic gene loci (abbreviations follow Shaklee et al. 1990): $m$ AAT-1*, $s \mathrm{AAT}-1,2 *, s \mathrm{AAT}-3 *, s \mathrm{AAT}-4 *, \mathrm{ADA}-1 *, \mathrm{ADA}-2 *, m \mathrm{AH}-$ $4^{*}, s \mathrm{AH}^{*}, \mathrm{FDHG}^{*}, \mathrm{GPI}-\mathrm{A}^{*}, \mathrm{GR}^{*}, m \mathrm{IDHP}-2^{*}, s \mathrm{IDHP}-1^{*}$, $s$ IDHP-2*, LDH-B2*, LDH-C*, $m \mathrm{MDH}-2 *, s \mathrm{MDH}-\mathrm{A} 1,2 *$, $s \mathrm{MDH}-\mathrm{B} 1,2 *, s \mathrm{MEP}-1 *$, MPI*, PEPA*, PEPB-1*, PEPD-2*, PEPLT $*, \mathrm{PGDH}^{*}, \mathrm{PGK}-2^{*}, \mathrm{PGM}-1 *, \mathrm{PGM}-2^{*}, s \mathrm{SOD}-1 *$, TPI-3*, TPI-4*.

Populations were selected to provide broad coverage of geographic and life-history diversity and to be representative of indigenous gene pools. Hatchery samples were used in some cases if the hatchery population was derived from a 


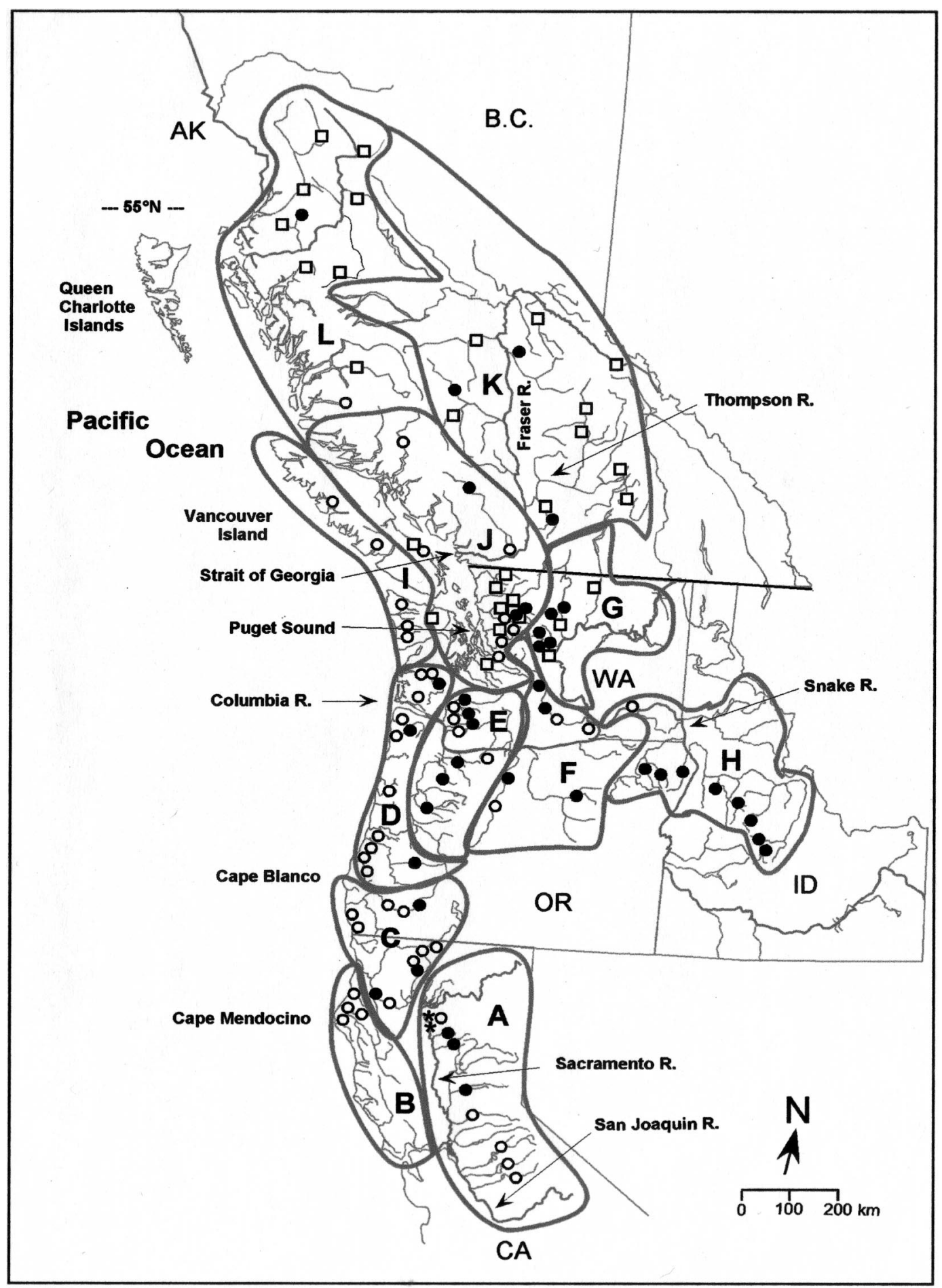

FIG. 2. Map of study area showing populations sampled for genetic and life-history data. Populations are coded by adult run time (see Appendices 1,2): closed circle, spring; open square, summer; open circle, fall; asterisk, winter. Twelve geographic provinces (A-L) used in the analysis of genetic and life-history data are outlined in bold.

local gene pool. Samples from multiple years were pooled within populations to provide an overall estimate of population allele frequencies. Mean sample size for the combined collections was 174 fish per population, with a range from 29 to 543 (Appendix 1). Collection dates spanned the years 1981-2000, although the majority of samples were collected from the mid-1980s to the mid-1990s (a period covering about two to three salmon generations). Previous studies (Utter et al. 1989; Waples and Teel 1990; Teel et al. 2000) have shown that the major features of Chinook salmon population genetic structure are stable over these time periods.

Allele frequency data for 77 of the populations have been 
TABLE 1. Hierarchical gene diversity analysis for Chinook salmon. Values in parentheses are the percent of the total gene diversity $\left(G_{\mathrm{ST}}\right)$ that is explained by that hierarchical level.

\begin{tabular}{lcccc}
\hline \hline $\begin{array}{c}\text { Sample/total } \\
\left(G_{\mathrm{ST}}\right)\end{array}$ & $\begin{array}{c}\text { Run/total } \\
\left(G_{\mathrm{RT}}\right)\end{array}$ & $\begin{array}{c}\text { Province/run } \\
\left(G_{\mathrm{PR}}\right)\end{array}$ & $\begin{array}{c}\text { Area/province } \\
\left(G_{\mathrm{AP}}\right)\end{array}$ & $\begin{array}{c}\text { Sample/area } \\
\left(G_{\mathrm{SA}}\right)\end{array}$ \\
\hline 0.138 & $0.014(10.2)$ & $0.085(62.0)$ & $0.019(13.9)$ & $0.019(13.9)$ \\
\hline
\end{tabular}

previously published (see Appendix 1). Additional data for many of those populations and data for the remaining populations are unpublished. (A complete set of allelic frequencies can be retrieved by accessing the website http:// www.nwfsc.noaa.gov/publications/). The genotypic frequencies for these samples generally conform to Hardy-Weinberg expectations (Utter et al. 1989; Bartley et al. 1992; Waples et al. 1993; Teel et al. 2000), and the banding patterns conform to expectations based on subunit structure of the enzymes, indicating that the data generally meet the criteria Utter et al. (1987) suggested for inferring a genetic basis for phenotypic variation of allozymes. In Chinook salmon, the duplicated loci $s \mathrm{AAT}-1,2^{*}, s \mathrm{MDH}-\mathrm{A} 1,2^{*}$, and $s \mathrm{MDH}-\mathrm{B} 1,2 *$ are considered isoloci (Waples 1988). In the analyses considered here, however, the observed genotypes were consistent with variation at a single gene locus, so the isolocus pairs were treated as a single locus with allele frequencies calculated as the mean across both loci.

Population genetic structure was evaluated in several ways. $G_{\mathrm{ST}^{-}}$-values were computed among pairs or groups of populations, and a hierarchical gene diversity analysis (Chakraborty 1980; Chakraborty et al. 1982) was used to partition $G_{\mathrm{ST}}$ into genetic variance related to geography and life history. Genetic relationships among populations were depicted using unrooted trees (PHYLIP; Felsenstein 1993) based on pairwise genetic distance values. We evaluated results using two distance measures (chord distance, Cavalli-Sforza and Edwards 1967; unbiased distance, Nei 1978) and two treebuilding algorithms (neighbor-joining and UPGMA). Because the major patterns were robust to the type of analysis, for simplicity we present results only for UPGMA trees using the chord distance. Robustness of tree topology was evaluated by performing 1000 bootstrap samples over the 32 loci.

\section{Life-History Data}

A recent review (Myers et al. 1998) of the status of Chinook salmon under the U.S. Endangered Species Act, together with additional sources, provided life-history data for the same set of populations examined in the genetic analysis (see Appendix 2 available online at http://dx.doi.org/10. 1554/03-323.1.s1). After considering a range of possible lifehistory traits, we focused on four for which adequate data were available and that covered a broad spectrum of the life cycle, including juvenile, marine, and adult phases. As discussed by Hard and Hershberger (1995) and below, a genetic basis has been demonstrated for each of these traits. Data were averaged across years to provide a mean trait value for each population.

Adult run timing.-Adult run timing (time of peak entry into fresh water on the adult spawning migration) is the lifehistory trait most commonly used to discriminate among and define salmon populations. All of the populations in the study could be characterized as belonging to one of four seasonal runs (peak run time of March-May, spring [S]; June-August, summer [SU]; September-November, fall [F]; DecemberFebruary, winter [W]), which facilitated comparisons with the genetic data.

Time of spawning._-We considered the month of peak spawning activity as a measure of reproductive behavior. The difference (in months) between peak run and peak spawn timing was used as an indication of the residence time of adults in fresh water before spawning.

Juvenile migration.-Salmon are known as smolts when they migrate to sea as juveniles. Chinook salmon typically smolt either in their first year of life (as subyearlings) or after spending an entire winter in fresh water (as yearlings), and

TABLE 2. Hierarchical gene diversity analysis of Chinook salmon within 12 geographic and ecological provinces. Values in columns are the percent of the total within-province gene diversity $\left(G_{\mathrm{SP}}\right)$ that is explained by that hierarchical level. Bold letters indicate the hierarchical level that explains the greatest amount of genetic diversity within each province.

\begin{tabular}{|c|c|c|c|c|}
\hline Province & $G_{\mathrm{SP}}$ & $\begin{array}{c}\text { Run/ } \\
\text { province }\end{array}$ & Area/run & Sample/area \\
\hline A. Central Valley & 0.018 & 38.9 & 5.6 & 55.6 \\
\hline B. Northern California & 0.015 & - & - & - \\
\hline D. Oregon/Washington coastal & 0.038 & 10.5 & 31.6 & 57.9 \\
\hline E. Lower Columbia & 0.050 & 32.0 & 42.0 & 26.0 \\
\hline F. Middle Columbia & 0.131 & 76.5 & 9.8 & 13.6 \\
\hline G. Upper Columbia & 0.164 & 93.9 & 2.4 & 3.6 \\
\hline J. Georgia Basin & 0.064 & 12.3 & 41.5 & 46.2 \\
\hline K. Upper Fraser & 0.067 & 7.6 & 25.8 & 66.7 \\
\hline L. Central British Columbia & 0.039 & 46.2 & 33.3 & 20.5 \\
\hline
\end{tabular}


this difference has been used by many authors (e.g., Gilbert 1912; Healey 1983, 1991) to distinguish Chinook salmon populations. We characterized each population according to the percentage of smolts that migrate as subyearlings, based on scale patterns in returning adults. Hatchery data were not used for this trait because age at smoltification can be strongly influenced by environmental conditions (Taylor 1990; Beckman and Dickhoff 1998). In some cases, juvenile life-history data for the natural source population were used to characterize a hatchery population for which we had genetic data.

Marine distribution. - Chinook salmon from the study area spend one to three (or rarely more) years at sea before commencing their spawning migration. We used the ocean harvest rate (percent of adult population captured in marine fisheries before they return to spawn) as an indication of the oceanic distribution of adults. These fisheries typically are conducted within 30 miles of shore, so they provide an indication of the presence of adults along the continental shelf. Harvest rates were based on fish marked as part of an extensive coastwide database (Pacific States Marine Fisheries Commission 2002). To minimize bias due to recent, region-specific harvest restrictions to address conservation concerns, we used harvest data from the decade 1980-1989 whenever possible.

Multivariate analysis._-Standardized scores for three lifehistory traits (smolt age, marine harvest rate, and run-spawn difference) were computed for 86 populations having data for all three traits. For each trait, an overall mean $(\bar{X})$ and standard deviation $\left(S_{x}\right)$ among populations were computed, and a standardized deviate for each population was computed as $\left(X_{i}-\bar{X}\right) / S_{x}$, where $X_{i}$ is the value for the trait in population $i$ (from Appendix Table 2). In cases where the value for a population consisted of a range rather than a point estimate, the midpoint of the range was used in this analysis.

\section{RESUlts}

\section{Genetic Analyses}

Results of our genetic analyses are consistent with other allozyme studies of Pacific salmon (e.g., Utter et al. 1989; Phelps et al. 1994) in finding quantitative (frequency) rather than qualitative (fixed) genetic differences among populations. Nevertheless, moderate genetic differentiation is evident over the geographic area covered, as indicated by the $G_{\mathrm{ST}^{-}}$-value for the overall dataset $(0.138)$. This is slightly higher than the value $(0.123)$ reported by Utter et al. (1989) for Chinook salmon from a slightly smaller geographic area and larger than $G_{\mathrm{ST}^{-}}$or $F_{\mathrm{ST}^{-}}$values that have been reported for comparable geographic areas for any other Pacific salmon species except sockeye salmon (O. nerka; Johnson et al. 1999; Altukhov et al. 2000).

The hierarchical gene diversity analysis partitioned the overall $G_{\mathrm{ST}^{-}}$-value into genetic variance related to run timing and geography: $G_{\mathrm{RT}}$, differences among run times within the total; $G_{\mathrm{PR}}$, among provinces within run times; $G_{\mathrm{AP}}$, among areas within provinces; $G_{\mathrm{SA}}$, among samples within areas (Table 1). For the overall dataset, $G_{\mathrm{RT}}$ was just 0.014 , indicating that run timing explained only $0.014 / 0.138=10.2 \%$ of the overall genetic differences among populations. Most of the differentiation was explained by geography $\left(G_{\mathrm{PR}}=\right.$ $\left.0.085,62.0 \% ; G_{\mathrm{AP}}=0.019,13.9 \%\right)$, with the remainder $\left(G_{\mathrm{SA}}\right.$
$=0.019,13.9 \%)$ resulting from differences among samples within areas. Because gene diversity analyses can be sensitive to the hierarchical structure used, we repeated the analysis with run time nested within geographic areas; the results were similar, with run timing explaining only $13.9 \%$ of the total differences among samples and geography explaining over $70 \%$ (data not shown).

Levels of genetic differentiation within geographic provinces varied considerably over the study area (Table 2). Relatively low levels of genetic differentiation $\left(G_{\mathrm{SP}}<0.02\right)$ were found within the California Central Valley and the Northern California Coast provinces, whereas differences within provinces in the interior Columbia River Basin were extensive $\left(G_{\mathrm{SP}}=0.091-0.164\right.$ for the mid and upper Columbia and Snake River provinces). The large $G_{\mathrm{SP}}$ for the upper Columbia province is consistent with the analysis of Utter et al. (1995) for that region. Other provinces were characterized by intermediate levels of population subdivision $\left(G_{\mathrm{SP}}=\right.$ $0.038-0.067)$. However, even within the provinces with relatively low $G_{\mathrm{SP}}$-values, highly significant genetic differences were found among almost every pair of populations. Overall, more than $99 \%$ of the pairwise comparisons among the 118 samples indicated highly significant differences in allele frequency $(P<0.01$ for a combined $G$-test over all gene loci). Thus, considerable fine-scale population genetic structure exists in Chinook salmon that is beyond the scope of this paper to consider.

The provinces also differ markedly in the proportion of the overall genetic differences that can be attributed to run timing. $G_{\mathrm{RP}}$ (run timing nested within provinces) explains the major fraction $(>70 \%)$ of the $G_{\mathrm{SP}}$ in the three provinces in the interior Columbia River Basin, whereas this life-history trait explains little (only about 10\%) of the differentiation in the Northern Coastal and Georgia Basin provinces (Table 2). Again, results were similar when the analysis was redone with run timing nested within area rather than province (data not shown).

The genetic distance analyses (Figs. 3, 4) provide additional and complementary insights into population genetic structure of Chinook salmon. The strong geographic component to the genetic structuring is apparent. Populations from the California Central Valley (province A), Northern California (B), upper Klamath (C1), coastal populations south of Cape Blanco (C2, C3), Washington coast (D, I1), lower Columbia (E1), upper Willamette (E2), and interior Fraser (K) all form discrete genetic groups with bootstrap support of $70-100 \%$. Populations in the upper Klamath and upper Willamette are notable in being strongly differentiated from all nearby populations. Other geographic and genetic groups of populations are also apparent (Puget Sound, J1; western Vancouver Island, I2; and central British Columbia, L) but not as strongly supported. Populations from the Strait of Georgia (J2; IDs 92-96) do not form a coherent genetic group and are plotted as outliers, as are Adams and Lower Shuswap (IDs 99, 100), two populations from the south Thompson River. In most cases, the relationships among the major geographic and genetic population groups are not well resolved (lack of strong bootstrap support in Fig. 3). A distinctive pattern found in the interior Columbia Basin (provinces $\mathrm{F}$, $\mathrm{G}, \mathrm{H}$ )-extreme genetic divergence between groups of pop- 


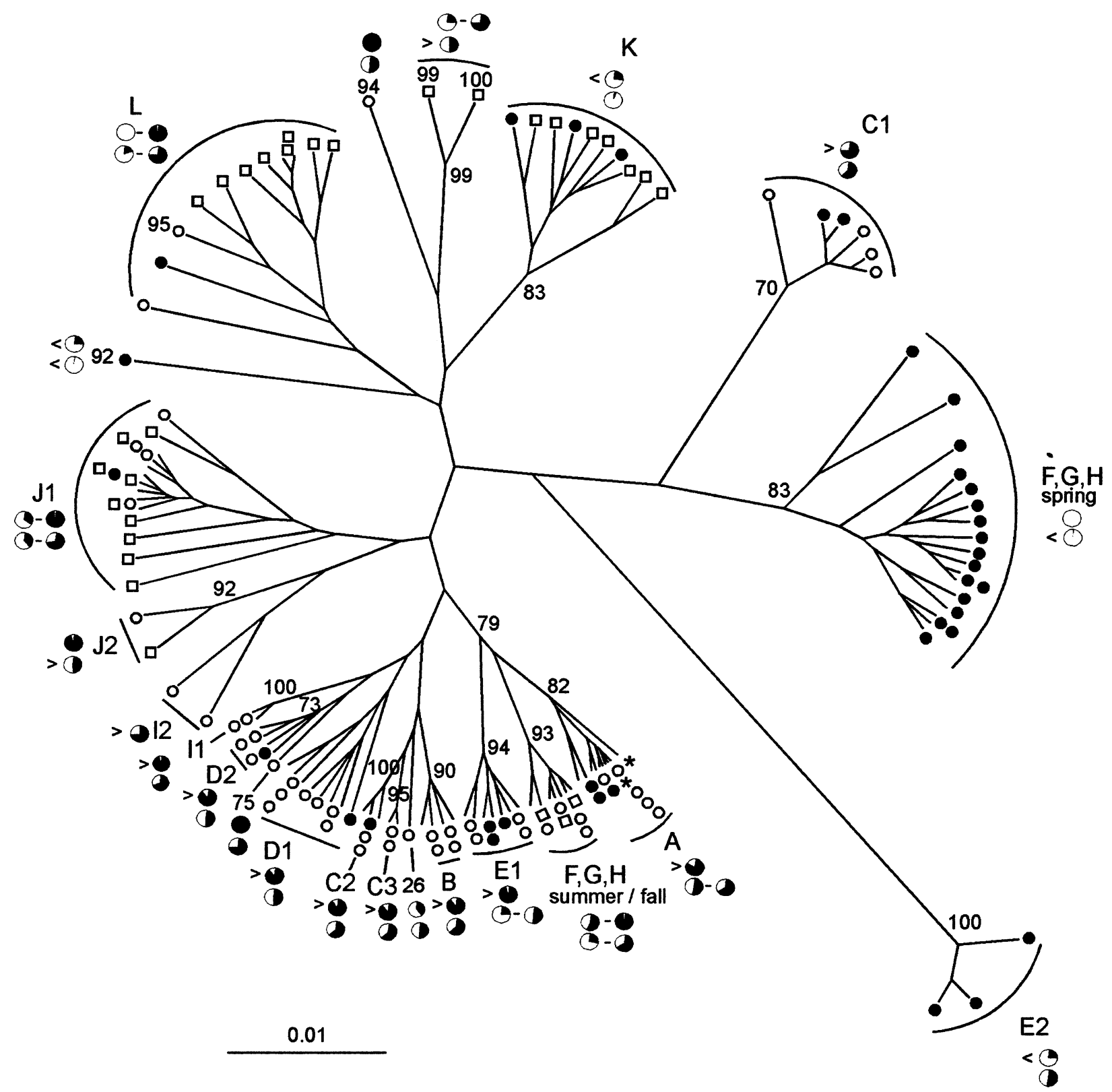

FIG. 3. UPGMA phenogram of genetic distances (Cavalli-Sforza and Edwards 1967) among 118 Chinook salmon populations. Upper case letters and numbers indicate provinces and areas, respectively, identified in Figure 2 and Appendix 1. Population symbols indicate adult run timing (Appendices 1,2): closed circle, spring; open square, summer; open circle, fall; asterisk, winter. Genetic outliers (populations not closely affiliated with other nearby populations) are identified by their population number (Appendix 1). Pie diagrams show the range of other life-history trait values (upper: percent subyearling smolts; lower: marine harvest rate). Numbers at branch points indicate bootstrap support $>70 \%$. Strong bootstrap support also exists for nodes within some labeled clusters but is not shown.

ulations in close geographic proximity-is discussed in more detail below. Our results extend the work of Utter et al. (1989), who identified nine major genetic groups of Chinook salmon from California to British Columbia and noted that within these groups genetic differences among different run times were generally relatively small.

\section{Life-History Analyses}

Run timing.-Mapping run-timing diversity onto the genetic relationships (Figs. 3, 4) confirms the two primary conclusions of the gene diversity analysis. First, geography has a much more profound influence on population genetic structure of Chinook salmon than does run timing. Spring-run populations are distributed broadly throughout the population genetic space and can be found in almost every major genetic group. Summer- and fall-run populations are also found in many divergent genetic groups; only the winter-run life history has a restricted geographic range, limited to the Sacramento River.

Second, in spite of this overall pattern, a strong association between population genetic structure and run timing is found within the interior Columbia River Basin. In this area up- 


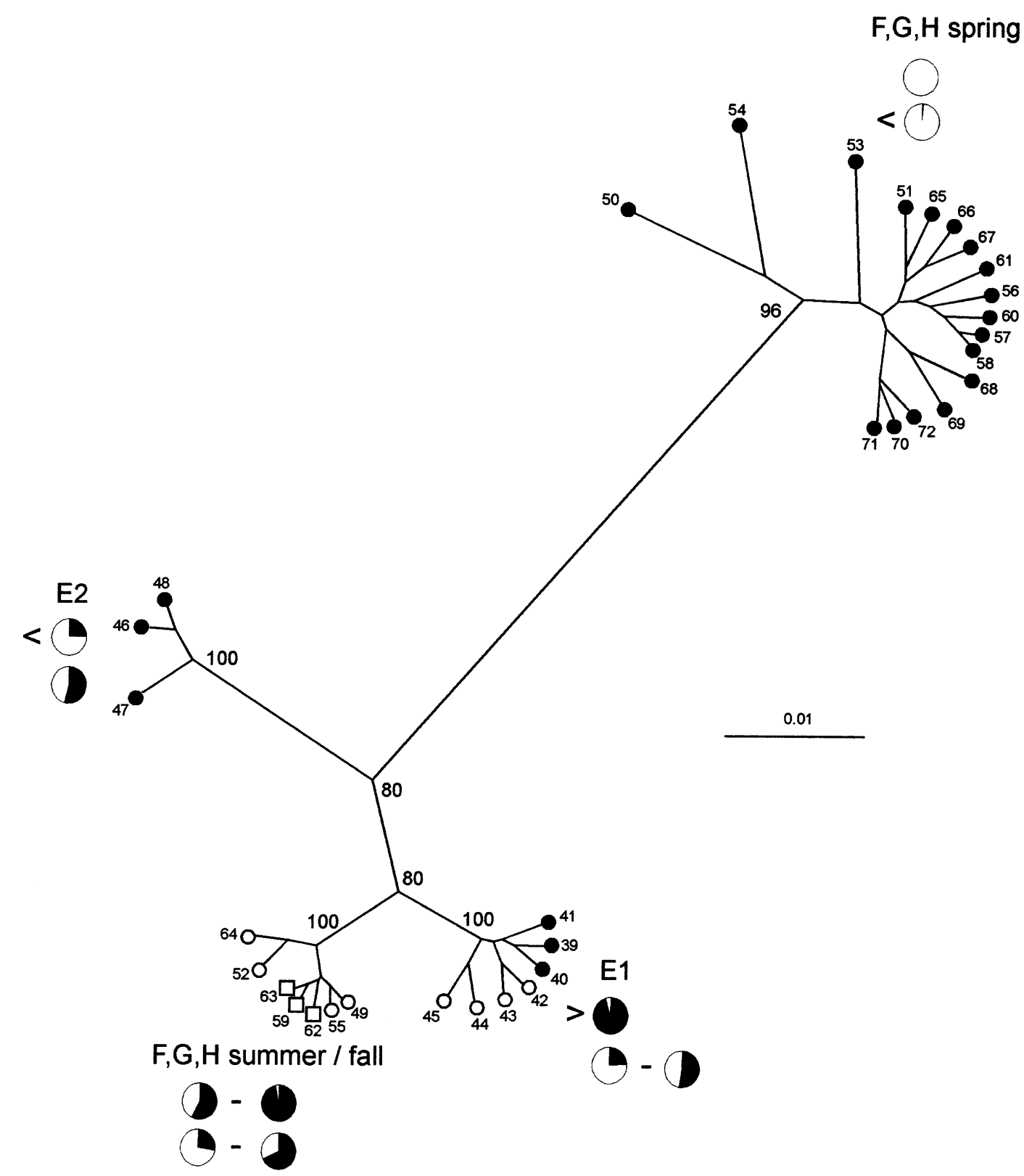

FIG. 4. UPGMA phenogram of genetic distances (Cavalli-Sforza and Edwards 1967) among 34 Chinook salmon populations from the Columbia River. Numbers, symbols, and labels correspond to those in Figure 3.

stream of the Cascade crest, all spring-run populations form a coherent genetic group that is strongly divergent from all the summer- and fall-run populations (Figs. 3, 4). Four separate lineages can be identified within the Columbia Basin, each with at least $96 \%$ bootstrap support (Fig. 4): lower Columbia River spring- and fall-run populations (E1); upper Willamette River populations (E2); interior Columbia summer- and fall-run populations (F, G, H); and interior Columbia spring-run populations $(\mathrm{F}, \mathrm{G}, \mathrm{H})$. The interior spring-run populations do not share a genetic affinity with spring-run populations from the lower Columbia River or coastal drainages in Oregon and Washington, but they do show some similarities to spring- and summer-run populations from Brit- ish Columbia and to populations in the upper Klamath (Figs. $3,4)$.

Juvenile migration.-Although many Chinook salmon populations have a mixture of subyearling and yearling smolts, when one considers the dominant life-history form in each population, a stronger geographic contrast is apparent than was found for run timing. In a broad geographic area ranging from the California Central Valley to British Columbia, virtually every population is dominated by subyearling smolts, whereas populations that are invariant (or nearly so) in producing yearling smolts are confined to the interior Columbia and Fraser Rivers (Figs. 3, 4). The only exceptions to this pattern are some coastal populations in Northern British Co- 
lumbia and the upper Willamette River populations, which have primarily yearling smolts and are genetically distinct from all other populations coastwide.

Marine distribution.-Marine distribution patterns (inferred from harvest rates) also differed substantially among populations in a pattern similar to that for smolt age. Harvest rates during the 1980 s were in excess of $50 \%$ of the total run for the majority of populations coastwide for which data are available (Appendix 2 online). In the same broad geographic area dominated by subyearling smolts, we did not find any population with a marine harvest rate lower than $24 \%$. In sharp contrast, many populations in the interior Columbia River basin and upper Fraser River scarcely appear at all in any marine fisheries (marine harvest rates estimated to be below 5\%, often below 1\%). It appears that Chinook salmon from these populations either are not present on the continental shelf during the periods the other populations are, or, if present, have behavioral patterns that do not make them susceptible to capture. The finding (Healey 1983; Myers et al. 1987) that Chinook salmon from these areas appear in disproportionate numbers in fisheries in the central North Pacific lends support to the former hypothesis

Multivariate analysis. - A trivariate plot of standardized scores for the three key life-history traits (Fig. 5) identifies a group of populations from the upper tributaries of the interior Columbia and Fraser Rivers with a very distinctive and tightly correlated suite of life-history traits (Birkenhead [ID 92], an upriver population of a tributary of the lower Fraser River, also shares these life-history traits). These populations all return to fresh water well before spawning (positive scores on the run-spawn axis), but that trait is also found in several coastal populations. What really distinguishes this group of populations is the combination of a fixed or nearly fixed yearling life-history strategy and a very low marine harvest rate. The remaining populations, including summer- and fallrun populations from the interior Columbia River, in general can be characterized as having subyearling smolts, high marine harvest rates, and a relatively short residence in fresh water before spawning. The similar geographic pattern for variation in smolt age and marine distribution is supported by correlation analysis of standardized scores for the lifehistory traits: a strong positive relationship $(r=0.76, P<$ $0.001)$ was found between the percent of subyearling smolts and harvest rate across all populations. Weaker (albeit still highly significant), and negative, correlations were found between run-spawn difference and smolt age and harvest rate ( $r=-054$ and -0.37 , respectively; both $P<0.001$ ).

\section{Rate of Life-History Evolution}

Joint consideration of the genetic and life-history data provides a means of estimating the length of isolation of populations with different run times and, hence, the rate of lifehistory evolution. Under the assumption that populations were once panmictic but are no longer exchanging genes, $F_{\mathrm{ST}}$ or $G_{\mathrm{ST}}$ can be interpreted as a function of long-term effective population size $\left(N_{e}\right)$ and time ( $t$, in generations) since isolation (Nei and Chakravarti 1977): $F_{\mathrm{ST}} \approx 1-e^{-t\left(2 N_{e}\right)}$. If $t$ is not too large $\left(t \ll 2 N_{e}\right)$, this expression can be simplified and rearranged to provide an estimate of divergence time $(\hat{t})$, given an estimate of $F_{\mathrm{ST}}$ (we used pairwise $G_{\mathrm{ST}}$-values for $\hat{F}_{\text {ST }}$ ) and an estimate of long-term (harmonic mean) effective size $\left(\hat{N}_{e}\right): \hat{t} \approx 2 \hat{F}_{\mathrm{ST}} \hat{N}_{e}$ generations. For comparisons of closely related populations, the appropriate value for $\hat{N}_{e}$ is the local effective population size; for comparisons of populations in divergent lineages (each comprised of several closely related populations), $F_{\mathrm{ST}}$ will be most strongly affected by the effective size of the lineages as a whole.

In the coastal basins and the lower Columbia River, the absolute levels of divergence between run types are low. For example, pairwise $G_{\mathrm{ST}}$-values between spring- and fall-run populations in eight basins from California to Puget Sound are all less than 0.02 (Fig. 6). If we consider $G_{\mathrm{ST}}=0.01$ to be typical for these comparisons, the second equation, above, yields $\hat{t} \approx(0.02) \hat{N}_{e}$. Assuming 1000 spawners per year per population (a plausible historic value for these populations; Puget Sound Technical Recovery Team 2001), a generation length of 4-5 years for Chinook salmon (Puget Sound Technical Recovery Team 2001; Waples 2002), and an $N_{e} / N$ ratio of 0.2-0.25 for Chinook salmon (Waples 2002, 2004), $\hat{N}_{e}$ is about 1000 per population per generation, leading to $\hat{t} \approx 20$ generations. Thus, the level of divergence in (presumably) neutral genes found between run times in a typical coastal basin could have arisen within approximately 80-100 years of complete isolation. Alternatively, under an equilibrium model that assumes observed genetic divergence represents a balance between migration ( $m$, fraction of immigrants per generation) and drift, $F_{\mathrm{ST}} \approx 1 /\left(1+4 m N_{e}\right.$ ) (Wright 1943). Under that model, a $G_{\mathrm{ST}}$ of 0.01 is consistent with the exchange of approximately 25 genetically effective migrants per generation (or about five to six per year for a typical Chinook salmon population).

In the interior Columbia Basin, pairwise $G_{\mathrm{ST}}$-values between spring-run and summer/fall-run populations are an order of magnitude larger $\left(G_{\mathrm{ST}}=0.12-0.16\right.$; Fig. 6). The two lineages occur in the closest geographic proximity in the upper Columbia River (province G), where spawning areas of spring- and summer-run populations may overlap in the lower reaches of the major tributaries. This province also has the highest gene diversity among populations $\left(G_{\mathrm{SP}}=0.164\right.$; Table 2), and over $94 \%$ of this results from differences between runs, leading to $G_{\mathrm{RP}}>0.15$, in agreement with the pairwise comparison of spring- and summer-run populations in the Methow River $\left(G_{\mathrm{ST}}=0.153\right.$; Fig. 6$)$. In an equilibrium model, $F_{\mathrm{ST}}=0.15$ implies slightly more than one successful migrant per generation among the two lineages, or about one every 4-5 years, a very low level of gene flow for populations that are essentially sympatric. Under an isolation model, $F_{\mathrm{ST}}$ $=0.15$ implies $\hat{t} \approx(0.3) \hat{N}_{e}$. Because most of the genetic difference between run-timing comparisons in the interior Columbia is due to differences between lineages, the rate of divergence is a primarily determined by the effective size of the lineages. If we assume $\hat{N}_{e}=10,000$ for each lineage, we are led to the conclusion that the observed genetic differences could have arisen in complete isolation over a period of approximately 3000 generations (about 12,000-15,000 years), or approximately since the end of the Pleistocene. If the longterm effective size of the two lineages was closer to 100,000 (not implausible, as historic estimates place the annual run size of Chinook salmon in the Columbia River at several 


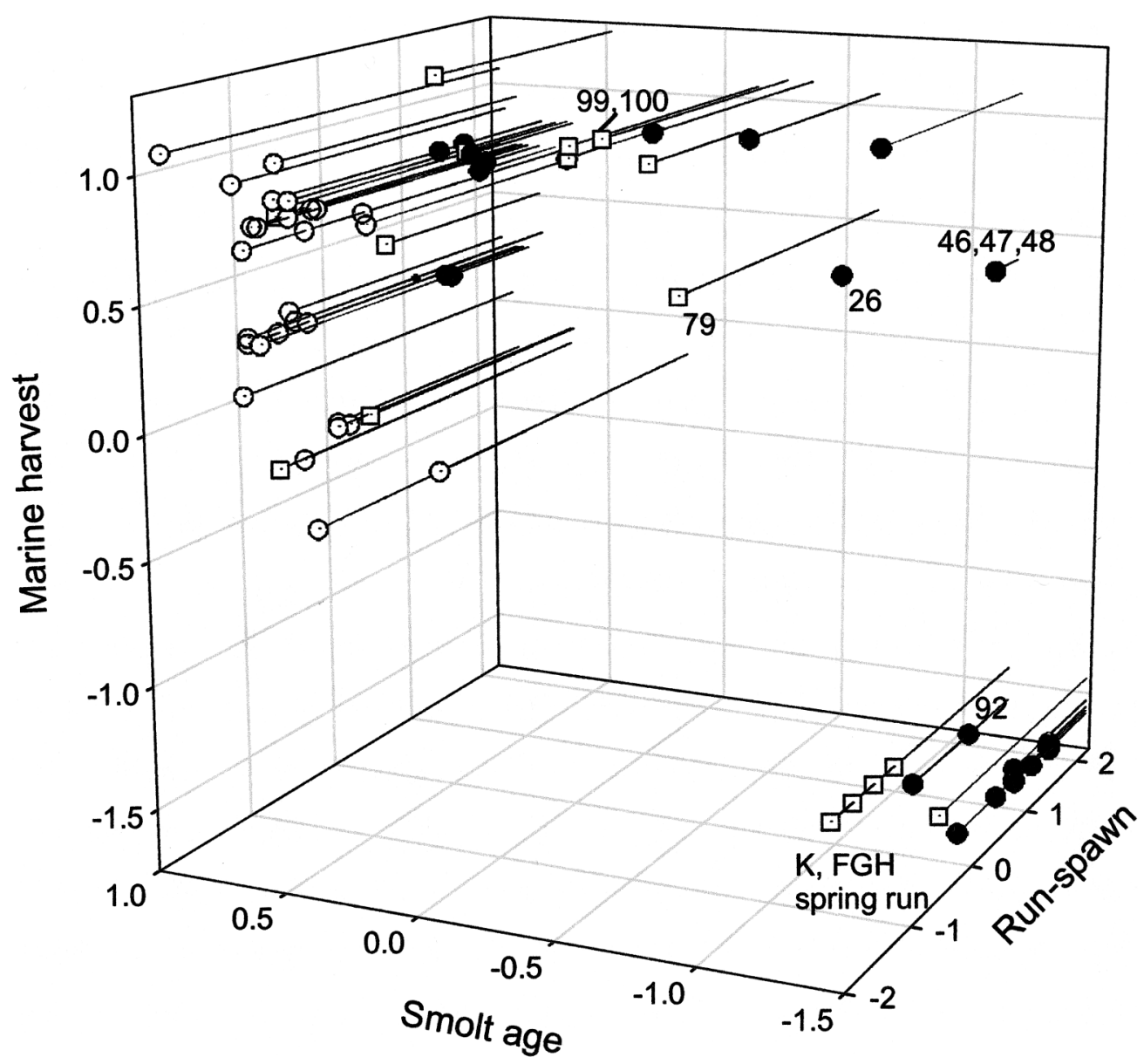

FIG. 5. Trivariate plot of variation among 78 Chinook salmon populations in three life-history traits, using standardized data from Appendix 2 online. Only populations with data for all three traits are plotted. Run-time symbols and labels correspond to those in Figure 3.

million adults; National Research Council 1996), the genetic data would be consistent with isolation of the two lineages for more than 100,000 years.

\section{DiscusSION}

\section{Patterns of Genetic and Life-History Differentiation}

The allozyme data identify two divergent lineages of Chinook salmon in the Columbia River Basin, a pattern also seen in recent studies of nuclear DNA (Ford 1998; Rasmussen et al. 2003) and mitochondrialDNA (Brannon et al. 2002). Congruent with these genetic differences are a suite of largely invariant juvenile and marine life-history traits (negligible marine harvest rates and exclusively yearling smolts) that distinguish interior Columbia spring-run populations from other Chinook salmon in the Columbia River. Outside the Columbia River, most interior Fraser River Chinook salmon share the life-history traits of the interior Columbia springrun populations, whereas most coastal populations from California to British Columbia share traits of the lower Columbia River populations.

This genetic/life-history dichotomy in the interior Columbia has some strong parallels with the two lineages of Chinook salmon proposed by Healey $(1983,1991)$. However, on a broader geographic scale it is apparent that the pattern of genetic/life-history relationships in Chinook salmon is more complicated than proposed by Healey or in other recent studies with a more restricted geographic scope (e.g., Teel et al. 2000). First, the extremely divergent upper Willamette River populations suggest that Healey's hypothesis of only two major lineages may be too simplistic. Willamette Falls, which is only passable to anadromous fish early in the spring, presumably is responsible for the uniquely early run timing of these populations and has apparently been an effective isolating mechanism for a considerable period of time, but the origins of this divergent group are not clear. The populations from the upper Klamath River Basin, which generally have ocean-type life-history traits but show some genetic affinity with interior Columbia stream-type fish, also do not fit cleanly into a dichotomous scheme involving two separate lineages. Second, the genetic affinity between interior Columbia and interior Fraser populations is not as strong as would be predicted assuming a common origin for all stream-type populations. Third, interior Fraser populations are not as strongly separated genetically from other Chinook salmon in British Columbia as are the stream- and ocean-type populations in the interior Columbia (pairwise $G_{\mathrm{ST}}$-values $\sim 0.06$ for the interior Fraser-Georgia Basin comparisons vs. $\sim 0.15$ in the Columbia; Fig. 6, Table 2). Nor is the pattern of differentiation as consistent in British Columbia as it is in the Colum- 


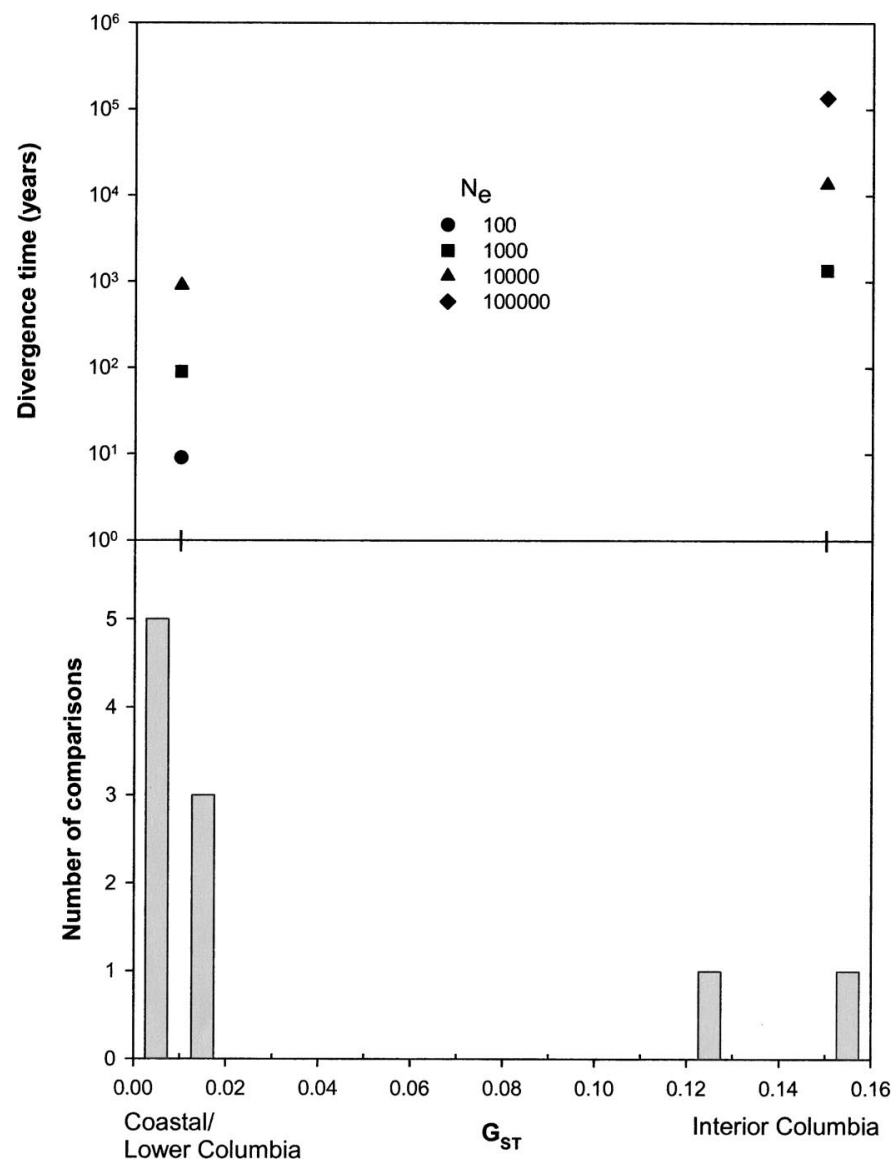

FIG. 6. Top: Estimates of divergence time for intrabasin comparisons of populations with different run types, based on $\hat{t} \approx 2 F_{\mathrm{ST}} N_{e}$, assuming an isolation model, plausible ranges of long-term $N_{e}$ values, and $G_{\mathrm{ST}}=0.01$ (coastal/lower Columbia River) or 0.15 (interior Columbia). Bottom: Distribution of pairwise $G_{\mathrm{ST}^{-}}$values between populations from the same basin with different run times (spring run vs. summer or fall run). Population comparisons (IDs for spring, summer/fall run) were as follows, in order of increasing $G_{\mathrm{ST}^{-}}$values: coastal/lower Columbia River: Sacramento $(6-8,9,10)$; Rogue (23, 24, 25); Cowlitz (39, 42); Skagit (78, 88); Lewis (41, $44)$; Klamath $(16,18)$; Kalama $(40,43)$; Trinity $(15,17)$. Interior Columbia: Deschutes $(50,52)$; Methow $(60,62)$.

bia River. For example, Birkenhead (92) has life-history traits characteristic of a stream-type population (Figs. 3, 5), but it is a genetic outlier with only a weak genetic affinity to interior stream-type populations, while some interior Fraser populations (Adams and Lower Shuswap, 99, 100) have oceantype life-history traits but genetically are somewhat intermediate to the other interior and coastal populations.

Finally, Healey's (1983, 1991) detailed analysis of Chinook life-history traits focused primarily on British Columbia and Alaskan populations and did not include the full range of life-history diversity within the ocean-type populations in the U.S. coastal ocean-type populations can return to spawn at any season of the year (not only fall, as indicated by Healey), and may spend as much as four to six months in fresh water before spawning (not the days or weeks indicated by Healey). Furthermore, Beckman (2002) showed that the trait classified here as subyearling smolt actually comprises at least three separate life-history trajectories, and Myers et al.
(1998) showed that the coastal populations migrate to a variety of different areas along the continental shelf. Life-history diversity within the ocean-type populations, therefore, is more extensive than described by Healey and merits more detailed treatment than can be afforded here.

Several different scenarios might explain the observed patterns in stream- and ocean-type Chinook salmon. First, assuming they are derived from separate lineages, more interbreeding of the two lineages may have occurred in British Columbia than in areas to the south. This mixing could have led to the mosaic pattern of genetic and life-history variation seen in several British Columbia populations. Based on microsatellite data, Beacham et al. (2003) suggested that mixing of the two lineages predated their invasion of the Fraser River following deglaciation. If this mixing occurred to different degrees in different areas of British Columbia and not at all in the Columbia, it could explain the observed pattern of genetic relationships. Second, because large parts of the Snake and Columbia River were ice-free during the last glacial period, stream-type populations from an earlier invasion might have persisted there during the Pleistocene, in spite of periodic deluges from glacial Lake Missoula that formed the channeled scablands of eastern Washington (Parfit 1995). A more recent, postglacial invasion of British Columbia from the north by the same ancestral lineage could explain the lack of close genetic affinity between the current populations in the interior Fraser and Columbia Basins. This hypothesis is testable with additional genetic data; if true, the interior Columbia and interior Fraser stream-type populations should both be more closely related to Alaskan populations than they are to each other. Finally, if Ford (1998) was correct in suggesting that there may not have been a northern glacial refugium for Chinook salmon, the current patterns in British Columbia could have resulted from various levels of interbreeding of two lineages reinvading from the south (rather than the north). More extensive sampling of Alaskan populations is necessary to resolve these uncertainties.

\section{Processes of Life-History Evolution}

We return now to the primary goal of this study-understanding the processes that have shaped life-history evolution in Chinook salmon - and the evolutionary conundrum posed in the introduction: Is life history diversity found in Chinook salmon the result of divergence during long periods of isolation, or is it more recently derived and evolutionarily labile? Results discussed above suggest that both processes have been important in producing the current landscape of Chinook salmon life-history diversity.

Run timing. - In coastal drainages and the lower Columbia and Fraser River Basins, none of the seasonal run times (except perhaps the winter run) is monophyletic. Each run time is found in a variety of genetic lineages, and populations with different run timing within a geographic area are genetically more similar to each other than to populations with similar run timing from different geographic areas-exactly the patterns expected to result from repeated episodes of parallel evolution (Fig. 1). Is it possible that populations with the same run timing really are monophyletic, and they just appear not to be in our analysis as a result of random error? The 
fact that two or more run times are found in many different genetic lineages with strong bootstrap support (A, C2, D2, $\mathrm{E} 1, \mathrm{~F}-\mathrm{H}$ summer/fall, J2, K) argues strongly against this possibility. As an additional test, we evaluated how many bootstrap replicates were consistent with a monophyletic origin of run timing diversity. For this test, we restricted the analysis to spring- and fall-run populations (separated by a minimum of three months, and a mean of five months, in peak run timing) to avoid possible effects of the somewhat arbitrary cutoff dates for seasonal run times. A replicate was judged consistent with a single origin of run-timing divergence if all of the genetic lineages in Figure 3 with more than $70 \%$ bootstrap support contained only spring- or only fall-run populations. Of 1000 bootstrap replicates, none satisfied this criterion. We conclude that parallel evolution of run-timing diversity has occurred many times in Chinook salmon. We believe that the direction of evolution has generally been from the more generalized fall-run type to the more specialized spring-run type.

A very different pattern of genetic/life-history relationships is seen in the interior Columbia Basin: all interior spring-run populations are genetically quite divergent from all summer/fall-run populations, consistent with the top panel in Figure 1 and providing no evidence for parallel evolution. Colonization of the various spring-run populations has apparently occurred through a process of radiation from a single lineage rather than evolving from a nearby summer- or fallrun population. In the interior Columbia Basin, therefore, the major run-time diversification represents a much older, and perhaps singular, evolutionary event.

That divergent selection for run timing can lead to rapid evolutionary change in Pacific salmon has been well established (e.g., Flagg et al. 1995; Quinn et al. 2002). The evidence for widespread parallel evolution of run timing differences in Chinook salmon is of particular interest because run timing is closely tied to spawn timing, which in turn directly affects the degree of reproductive isolation. It has been suggested (Bush 1994; Schluter and Nagel 1995; Johannesson 2001) that divergent natural selection on traits related to reproductive isolation can lead to sympatric parallel speciation, and data presented by Taylor et al. (1996) suggest that such a process may be occurring in sockeye salmon $(O$. nerka). However, we found no evidence for parallel speciation in Chinook salmon. Although run timing differentiation within a river basin might be expected to increase opportunities for reproductive isolation, the genetic data suggest that in most cases this process has been retarded by ongoing gene flow between the run types. It appears that divergent natural selection on run and spawn timing is not sufficient to overcome the effects of gene flow in coastal basins, which may not be large enough to provide substantial opportunities for geographic separation (and hence genetic isolation) of the different run types. Strong genetic differences associated with run timing are found only in the interior Columbia (and, to a lesser extent, the interior Fraser), which does provide ample opportunities for extensive geographic and genetic isolation. For example, in the Snake River, fall Chinook salmon are primarily mainstem spawners that historically inhabited reaches of about 500-1000 m elevation, whereas spring Chinook salmon spawn in upper tributaries at elevations of 1500-
$2000 \mathrm{~m}$. If extensive geographic separation is necessary for substantial genetic differences to accumulate between run types in Chinook salmon, it would suggest that the large differences found between spring and summer/fall Chinook in the upper Columbia (where the two forms live in close proximity) are the result of secondary contact rather than evolutionary divergence in situ.

Juvenile migration. - A number of coastal populations have a moderate proportion of yearling smolts, and it is possible that a genetic tendency to produce yearling smolts has evolved several times from the subyearling phenotype most commonly found in coastal Chinook salmon populations. However, smolt age is also known to be one of the most labile traits in Chinook salmon and can be affected by growth rate, photoperiod, or other factors (Clarke et al. 1994; Beckman and Dickhoff 1998). Diversity in age at smolting may be adaptive in areas that are particularly prone to yearly fluctuations in stream flow and water temperature. The occurrence of yearling smolts in some populations that have allozyme profiles similar to nearby subyearling populations may be a response to environmental conditions that vary in space and time. However, more research is needed to determine whether this reflects evolution toward a stable, genetically based polymorphism or evolution of phenotypic plasticity per se (Via et al. 1995).

Marine distribution. - Marine distribution patterns appear to be the most invariant of the life-history traits examined here, and we found little evidence for parallel evolution. Ranging widely off the continental shelf appears to be a trait characteristic of all interior stream-type populations. In sharp contrast, our data support the conclusions of previous authors (Healey 1983; Myers et al. 1987) that Chinook salmon from coastal ocean-type populations are present on the continental shelf throughout their adult lives and are not commonly found in the central North Pacific. Given the ambiguity of genetic evidence for monophyly of the stream-type lineage, we cannot be certain that the offshore migration pattern evolved only once in Chinook salmon, but in any case the evolvability of this trait appears to be much more limited than is the case for run timing or smolt age. Notably, we found no evidence that the coastal, ocean-type lineage has produced any populations in which most individuals range widely off the continental shelf during their marine phase.

This trait also does not show evidence of phenotypic plasticity. Translocation of populations to novel geographic areas (and hatchery programs that force ocean-type populations to smolt as yearlings rather than subyearlings) do not result in substantial changes in marine harvest patterns (J. M. Myers, unpubl. data), suggesting a limited role for environmental influences. Similar results for coho salmon (O. kisutch; Weitkamp et al. 1995) suggest a strong genetic basis to marine distribution patterns in that species as well.

Life-history constraints.-In spite of the sensitivity of smolt age to environmental conditions, the yearling smolt phenotype is fixed or nearly fixed in interior stream-type populations. In these populations, returning adults that went to sea as subyearling smolts are essentially nonexistent (Taylor 1990), and hatchery programs that have attempted to force interior Columbia stream-type fish into a subyearling smolt phenotype have not been effective in producing adults ( $R$. 
Carmichael, pers. comm.). Thus, although it may be possible to induce a population with a yearling smolt phenotype to smolt as subyearlings (and vice versa), the subyearling lifehistory trajectory does not appear to be viable in the natural habitat of the interior Columbia. Why should this be the case?

We believe that the distinctive marine ecology of the interior stream-type populations may be an important constraint to expression of other life-history features, either directly or indirectly. Juveniles must reach the sea at a time conducive to growth and survival in the marine environment. Healey (1983, 1991) and others have shown that the early ocean ecologies of stream- and ocean-type Chinook salmon differ considerably: juveniles from coastal populations typically spend weeks or months in estuaries or nearshore marine environments, whereas juveniles from interior populations migrate rapidly to the north and off the continental shelf. Welch et al. (2002) monitored marine migration rates in juvenile Chinook salmon and found that Snake River populations migrated the fastest, with some individuals migrating at over two body lengths per second for periods of at least one month. Smolting in the spring and rapidly migrating northward and offshore to the preferred marine habitat appears to be an essential link in the life cycle of Chinook salmon from interior stream-type populations; smolting as subyearlings (and hence later in the previous year) may not deliver juveniles to the ocean at a time that is conducive to growth and survival in the part of the marine environment they occupy as adults.

Given the constraint of producing yearling smolts, the environmental conditions in the headwater streams inhabited by the interior stream-type populations (characterized by low water temperatures, a short growing season, and seasonal flows) may constrain the populations to early run timing. Adults must return to fresh water early enough to take advantage of snowmelt runoff in the upper tributaries and must spawn early enough to provide sufficient thermal units (Brannon 1987) for the embryos to fully develop in the cold water by spring.

\section{Rate of Life-History Evolution}

Estimates of divergence time based on the genetic data should be regarded as only rough approximations, given the uncertainty about the appropriate model and the numerous underlying assumptions. Nevertheless, the data indicate that in coastal drainages and in the lower Columbia River, genetic differences between populations with different run timing are small enough that they could have arisen within about 80 100 years of complete isolation-comparable to the amount of time within which Chinook salmon transplanted to New Zealand have shown similar levels of life-history evolution (Quinn et al. 1996). Because this is considerably less than the amount of time available for life-history evolution in even the most recently glaciated coastal drainages, and because we are not aware of any events that would have caused recent isolation of many populations with different run timing, we believe it is likely that run-timing diversity in these areas evolved much earlier than a century ago, but genetic divergence at neutral markers has been retarded by ongoing or episodic gene flow. Thus, although the failure of most stock transfers indicates that local populations may be largely ir- replaceable on human time frames, at least some patterns of Chinook salmon life-history diversity appear to be evolutionarily replaceable, perhaps over time frames of a century or so. The evidence for repeated parallel evolution of run timing in Chinook salmon indicates that such a process is likely, provided that habitats capable of supporting alternative life-history trajectories are present and sufficient, robust source populations are maintained.

Some patterns of life-history traits are more strongly conserved and perhaps have evolved only once. In the interior Columbia, genetic data suggest that two groups of populations with highly divergent and tightly correlated life history straits either have been completely isolated for a considerable time (perhaps $10^{4}-10^{5}$ years), or have exchanged genes at a very low level (about one per generation between the two lineages). In either case, the two lineages are effectively behaving as separate biological species in sympatry.

If all interior stream-type populations were lost (and most in the interior Columbia are now listed as threatened or endangered species under the U.S. Endangered Species Act; http://www.nwr.noaa.gov), it is reasonable to expect that fish from ocean-type populations might eventually evolve the early run timing and yearling smolt life history to allow them to use upper level tributaries. However, empirical data provide no reason to expect that these populations would evolve the ability to use the vacated marine habitat off the continental shelf. Loss of these interior populations would therefore represent a loss of ecological and genetic diversity that might be difficult to replace even on evolutionary time frames. These evolutionary considerations are reflected in the identification of evolutionarily significant units (ESUs) of Chinook salmon, which can be considered for listing as species under the Endangered Species Act (Waples 1991, 1995). In coastal and lower Columbia River drainages, ESUs largely reflect the major geographic and genetic units identified in Figures 2 and 3, with run-timing differences generally considered as reflecting patterns of within-ESU diversity (Myers et al. 1998). In the interior Columbia Basin, however, where run-timing differences reflect a much older divergence, spring- and fall-run populations are in separate ESUs (Ford 2004).

\section{ACKNOWLEDGMENTS}

We thank J. Candy, R. Carmichael, and C. Parken for providing unpublished life-history data and B. Beckman, J. Felsenstein, P. Smouse, and J. Johnson for thoughtful discussions. K. Neely helped draft the figures. The manuscript was considerably improved as a result of insightful comments by B. Beckman, L. Bernatchez, E. Brannon, J. Candy, M. Ford, S. Grant, J. Hard, J. Johnson, C. Parken, E. Taylor, F. Utter, and two anonymous reviewers.

\section{Literature Cited}

Aebersold, P. B., G. A. Winans, D. J. Teel, G. B. Milner, and F. M. Utter. 1987. Manual for starch gel electrophoresis: a method for the detection of genetic variation. U.S. Dept. Commerce, NOAA Tech. Rep. NMFS 61.

Allendorf, F. W., and R. S. Waples. 1996. Conservation and genetics of salmonid fishes. Pp. 238-280 in J. C. Avise and J. L. Hamrick, 
eds. Conservation genetics: case histories from nature. Chapman and Hall, New York.

Altukhov, Y. P., E. A. Salmenkova, and V. T. Omelchenko. 2000. Salmonid fishes: population biology, genetics, and management. Blackwell Science, London.

Bailey, R. E., J. R. Irvine, J. R. Candy, C. K. Parken, S. L. Lemke, M. Sullivan, and M. Wetklo. 2001. Summary of stock assessment information for selected early returning Chinook salmon populations of the Fraser River watershed. Canadian Science Advisory Secretariat. Research Document 2001/134.

Bartley, D., B. Bentley, J. Brodziak, R. Gomulkiewicz, M. Mangel, and G. A. E. Gall. 1992. Geographic variation in population genetic structure of Chinook salmon from California and Oregon. Fish. Bull. (U.S.) 90:77-100. (Authorship amended per errata, Fish. Bull. 90[3]:iii.)

Beacham, T. D., K. J. Supernault, M. Wetklo, B. Deagle, K. Labaree, J. R. Irvine, J. R. Candy, K. M. Miller, R. J. Nelson, and R. E. Withler. 2003. The geographic basis for population structure in Fraser River Chinook salmon (Oncorhynchus tshawytscha). Fish. Bull. (U.S.) 101:229-242.

Beckman, B. R. 2002. Growth and the plasticity of smolting in Chinook salmon. Ph.D. diss., University of Washington, Seattle, WA.

Beckman, B. R., and W. W. Dickhoff. 1998. Plasticity of smolting in spring Chinook salmon: relation to growth and insulin-like growth factor-I. J. Fish Biol. 53:808-826.

Bernatchez, L. 1995. A role for molecular systematics in defining evolutionary significant units (ESU) in fishes. Am. Fish. Soc. Symp. 17:114-132.

Bernatchez, L., J. A. Vuorinen, R. A. Bodaly, and J. J. Dodson. 1996. Genetic evidence for reproductive isolation and multiple origins of sympatric trophic ecotypes of whitefish (Coregonus). Evolution 50:624-635.

Brannon, E. L. 1987. Mechanisms stabilizing salmonid fry emergence timing. Pp. 219-227 in E. L. Brannon and E. O. Salo, eds. Proceedings of salmon and trout migratory behavior symposium. Univ. of Washington, Seattle, WA.

Brannon, E. L., M. Powell, T. Quinn, and A. Talbot. 2002. Population structure of Columbia River Basin Chinook salmon and steelhead trout. Final Report. Center for Salmonid and Freshwater Species at Risk, Univ. of Idaho, Moscow.

Bugert, R., C. Busack, G. Mendel, K. Peterson, D. Marbach, L. Ross, and J. Dedloff. 1991. Lyons Ferry fall Chinook salmon hatchery evaluation program. 1990 annual report of Washington Dept. of Fisheries to U.S. Fish and Wildlife Service, Boise, ID.

Busack, C., C. Knudsen, A. Marshal, S. Phelps, and D. Seiler. 1991. Yakima hatchery experimental design. Annual Progress Report to Bonneville Power Administration under contract DE-B17989BP00102. Available from BPA, P.O. Box 3621, Portland, OR 97208.

Bush, G. L. 1994. Sympatric speciation in animals: new wine in old bottles. Trends Ecol. Evol. 9:285-288.

Candy, J. R., J. R. Irvine, C. K. Parken, S. L. Lemke, R. E. Bailey, M. Wetklo, and K. Jonsen. 2002. A discussion paper on possible new stock groupings (conservation units) for Fraser River Chinook salmon. Canadian Stock Assessment Secretariat. Research Document 2002/085. Available from CSAS 200 Kent St., Ontario, K1A 0E6, Canada or http://www.dfo-mpo.gc.ca/csas/.

California Department of Fish and Game. 1996. The status of the Sacramento River spring-run Chinook salmon. A special report to the Fish and Game Commission. Inland Fisheries Division, California Fish and Game.

Cavalli-Sforza, L. L., and A. W. F. Edwards. 1967. Phylogenetic analysis: models and estimation procedures. Evolution 21: 550-570.

Chakraborty, R. 1980. Gene diversity analysis in nested subdivided populations. Genetics 96:721-726.

Chakraborty, R., M. Haag, N. Ryman, and G. Stahl. 1982. Hierarchical gene diversity analysis and its application to brown trout population data. Hereditas 97:17-21.

Clarke, W. C., R. E. Withler, and J. E. Shelbourn. 1994. Inheritance of smolting phenotypes in backcrosses of hybrid stream-type $\mathrm{X}$ ocean-type Chinook salmon (Oncorhynchus tshawytscha). Estuaries 17:13-25.

Connor, W. P., H. L. Burge, R. Waitt, and T. C. Bjornn. 2002. Juvenile life history of wild fall Chinook salmon in the Snake and Clearwater Rivers. N. Am. J. Fish. Manage. 22:703-712.

Crandall, K. A., O. R. P. Bininda-Emonds, G. M. Mace, and R. K. Wayne. 2000. Considering evolutionary processes in conservation biology. Trends Ecol. Evol. 15:290-295.

Felsenstein, J. 1993. PHYLIP (phylogeny inference package). Ver. 3.57. Dept. of Genetics, Univ. of Washington, Seattle, WA.

Flagg, T. A., F. W. Waknitz, D. J. Maynard, G. B. Milner, and C. V. W. Mahnken. 1995. The effect of hatcheries on native coho salmon populations in the lower Columbia River. Am. Fish. Soc. Symp. 15:366-375.

Ford, M. J. 1998. Testing models of migration and isolation among populations of Chinook salmon (Oncorhynchus tshawytscha). Evolution 52:539-557.

Ford, M. J. 2004. Conservation units and preserving diversity. Pp. 338-357 in A. P. Hendry and S. C. Stearns, eds. Evolution illuminated: salmon and their relatives. Oxford Univ. Press, Oxford, U.K.

Fraser, F. J., P. J. Starr, and A. Y. Fedorenko. 1982. A review of the Chinook and coho salmon of the Fraser River. Canadian Tech. Rpt. Fisheries and Aquatic Sciences 1126.

Gilbert, C. H. 1912. Age at maturity of Pacific coast salmon of the genus Oncorhynchus. Bull. U.S. Fish Comm. 32:57-70.

Groot, C., and L. Margolis. 1991. Pacific salmon life histories. Univ. of British Columbia Press, Vancouver, Canada.

Gustafson, R. G., R. S. Waples, S. T. Kalinowski, and G. A. Winans. 2001. Evolution of sockeye salmon ecotypes. Science 291:251.

Hard, J. J., and W. K. Hershberger. 1995. Quantitative genetic consequences of captive broodstock programs for anadromous $\mathrm{Pa}-$ cific salmon (Oncorhynchus spp.). Pp. 2-1-2-75 in T. A. Flagg and C. V. W. Mahnken, eds. An assessment of the status of captive broodstock technology for Pacific salmon. Available Bonneville Power Administration (Project no. 93-56), P.O. Box 3621, Portland, OR 97208-3621.

Healey, M. C. 1983. Coastwide distribution and ocean migration patterns of stream- and ocean-type Chinook salmon, Oncorhynchus tshawytscha. Can. Field-Nat. 97:427-433.

___ 1991. Life history of Chinook salmon (Oncorhynchus tshawytscha). Pp. 311-393 in C. Groot and L. Margolis, eds. Pacific salmon life histories. Univ. of British Columbia Press, Vancouver, Canada.

Hendry, A. P., and M. T. Kinnison. 1999. The pace of modern life: measuring rates of contemporary microevolution. Evolution. 53: 1637-1653.

Hendry, A. P., J. K. Wenburg, P. Bentzen, E. C. Volk, and T. P. Quinn. 2000. Rapid evolution of reproductive isolation in the wild: evidence from introduced salmon. Science 290:516-518.

Johannesson, K. 2001. Parallel speciation: a key to sympatric divergence. Trends Ecol. Evol. 16:148-153.

Johnson, J. B. 2001. Adaptive life-history evolution in the livebearing fish Brachyrhaphis rhabdophora: genetic basis for parallel divergence in age and size at maturity and a test of predatorinduced plasticity. Evolution 55:1486-1491.

Johnson, O. W., M. H. Ruckelshaus, W. S. Grant, F. W. Waknitz, A. M. Garrett, G. J. Bryant, K. Neely, and J. J. Hard. 1999. Status review of coastal cutthroat trout from Washington, Oregon, and California. NOAA Tech. Memo. NMFS-NWFSC37.

Kinnison, M. T., M. J. Unwin, N. Boustead, and T. P. Quinn. 1998. Population specific variation in body dimensions of adult Chinook salmon (Oncorhynchus tshawytscha) from New Zealand and their source population, 90 years after their introduction. Can. J. Fish. Aquat. Sci. 55:554-563.

Kwain, W., and E. Thomas. 1984. The first evidence of spring spawning by Chinook salmon in Lake Superior. N. Am. J. Fish. Manage. 4:227-228.

McPhail, J. D., and C. C. Lindsey. 1986. Zoogeography of the freshwater fishes of Cascadia (the Columbia system and rivers north to the Stikine). Pp. 615-637 in C. H. Hocutt and E. O. 
Wiley, eds. The zoogeography of North American freshwater fishes. John Wiley and Sons, New York.

Milner, G. B., D. J. Teel, P. B. Aebersold, and F. M. Utter. 1986. Genetic Stock Identification. Report to Bonneville Power Administration under contract DE-A179-85BP23520. Available from BPA, P.O. Box 3621, Portland, OR 97208.

Myers, J. M., R. G. Kope, G. J. Bryant, D. Teel, L. J. Lierheimer, T. C. Wainwright, W. S. Grant, F. W. Waknitz, K. Neely, S. T. Lindley, and R. S. Waples. 1998. Status review of Chinook salmon from Washington, Idaho, Oregon, and California. U.S. Dept. Commerce, NOAA Tech. Memo. NMFS-NWFSC-35.

Myers, K. W., C. K. Harris, C. M. Knudsen, R. V. Walker, N. D. Davis, and D. E. Rogers. 1987. Stock origins of Chinook salmon from the area of the Japanese mothership salmon fishery. N. Am. J. Fish. Manage. 7:459-474.

Myers, N., and A. H. Knoll. 2001. The biotic crisis and the future of evolution. Proc. Natl. Acad. Sci. USA 98:5389-5392.

National Research Council. 1996. Upstream: salmon and society in the Pacific Northwest. National Academy Press, Washington, DC.

Nehlsen, W., J. E. Williams, and J. A. Lichatowich. 1991. Pacific salmon at the crossroads: stocks at risk from California, Oregon, Idaho, and Washington. Fisheries 16:4-21.

Nei, M. 1978. Estimation of average heterozygosity and genetic distance from a small number of individuals. Genetics 89: 583-590.

Nei, M., and A. Chakravarti. 1977. Drift variances of $F_{\mathrm{ST}}$ and $G_{\mathrm{ST}}$ statistics obtained from a finite number of isolated populations. Theor. Popul. Biol. 11:307-325.

Nicholas, J. W., and D. G. Hankin. 1988. Chinook salmon populations in Oregon coastal river basins: description of life histories and assessment of recent trends in run strengths. Oregon Dept. Fish Wildlife, Fisheries Div. Info. Rep. no. 88-1.

Pacific Salmon Commission. 2001. Joint Chinook technical committee report: annual exploitation rate analysis and model calibration. Report TCChinook (01-2).

Pacific States Marine Fisheries Commission. 2002. Regional mark information system, coded-wire tag database website: http:// www.rmis.org/cwt/cwt_qbe.html.

Parfit, M. 1995. The floods that carved the West. Smithsonian 26: 48-59.

Parrish, D. L., R. J. Behnke, S. R. Gephard, S. D. McCormick, and G. H. Reeves. 1998. Why aren't there more Atlantic salmon (Salmo salar)? Can. J. Fish. Aquat. Sci. 55(Suppl 1):281-287.

Phelps, S. R., L. L. LeClair, S. Young, and H. L. Blankenship. 1994. Genetic diversity patterns of chum salmon in the Pacific Northwest. Can. J. Fish. Aquat. Sci. 51(Suppl. 1):65-83.

Pigeon, D., A. Chouinard, and L. Bernatchez. 1997. Multiple modes of speciation involved in the parallel evolution of sympatric morphotypes of lake whitefish (Coregonus clupeaformis). Evolution 51:196-205.

Pimm, S. L., and P. Raven. 2000. Extinction by the numbers. Nature 403:843-845.

Puget Sound Technical Recovery Team. 2001. Independent populations of Chinook salmon in Puget Sound. Draft report, available at http://research.nwfsc.noaa.gov/trt/trt_puget.htm.

Quinn, T. P., J. L. Nielsen, C. Gan, M. J. Unwin, R. Wilmot, C. Guthrie, and F. M. Utter. 1996. Origin and genetic structure of Chinook salmon, Oncorhynchus tshawytscha, transplanted from California to New Zealand: allozyme and mtDNA evidence. Fish. Bull. (U.S.) 94:506-521.

Quinn, T. P., M. J. Unwin, and M. T. Kinnison. 2000. Evolution of temporal isolation in the wild: genetic divergence in timing of migration and breeding in introduced populations of Chinook salmon. Evolution 54:1372-1385.

Quinn, T. P., J. A. Peterson, V. F. Gallucci, W. K. Hershberger, and E. L. Brannon. 2002. Artificial selection and environmental change: countervailing factors affecting the timing of spawning by coho and Chinook salmon. Trans. Am. Fish. Soc. 131: 591-598.

Rasmussen, C., C. O. Ostberg, D. R. Clifton, J. L. Holloway, and R. J. Rodriguez. 2003. Identification of a genetic marker that discriminates ocean-type and stream-type Chinook salmon in the Columbia River Basin. Trans. Am. Fish. Soc. 132:131-142.

Reznick, D. N., and C. K. Ghalambor. 2001. The population ecology of contemporary adaptations: What empirical studies reveal about the conditions that promote adaptive evolution? Genetica $24: 1-16$

Reznick, D. N., F. Helen Rodd, and M. Cardenas. 1996. Life-history evolution in guppies (Poecilia reticulata: Poeciliidae). IV. Parallelism in life history phenotypes. Am. Nat. 147:319-338.

Ricker, W. E. 1972. Hereditary and environmental factors affecting certain salmonid populations. Pp. 19-160 in R. C. Simon and P. A. Larkin, eds. The stock concept in Pacific salmon. H. R. MacMillan Lectures in Fisheries. Univ. of British Columbia Press, Vancouver, Canada.

Roff, D. A. 1992. The evolution of life histories: theory and analysis. Chapman and Hall, New York.

Roni, P. 1992. Life history and spawning habitat in four stocks of large-bodied Chinook salmon (Oncorhynchus tshawytscha). M.Sc. thesis, University of Washington, Seattle, WA.

Rundle, H. D., L. Nagel, J. W. Boughman, and D. Schluter. 2000. Natural selection and parallel speciation in sympatric sticklebacks. Science 287:306-308.

Schluter, D., and L. M. Nagel. 1995. Parallel speciation by natural selection. Am. Nat. 146:292-301.

Shaklee, J. B., and S. Phelps. 1990. Operation of a large-scale, multiagency genetic stock identification program. Am. Fish. Soc. Symp. 7:817-830.

Shaklee, J. B., F. W. Allendorf, D. C. Morizot, and G. S. Whitt. 1990. Gene nomenclature for protein-coding loci in fish. Trans. Am. Fish. Soc. 119:2-15.

Shepherd, B. G, J. E. Hillaby, and R. J. Hutton. 1986. Studies on Pacific salmon (Oncorhynchus spp.) in phase I of the salmonids enhancement program. Vol. II, Data appendices. Can. Tech. Rep. Fish. Aquat. Sci. 1482:1-180.

Snider, B., B. Reavis, and S. Hill. 1999. 1998 Upper Sacramento River winter-run Chinook salmon escapement survey May-August 1998. California Dept. of Fish and Game.

Taylor, E. B. 1989. Adaptive diversification of juvenile life histories in the Chinook salmon, Oncorhynchus tshawytscha (Walbaum). Ph.D. diss., University of British Columbia, Vancouver, Canada. 1990. Environmental correlates of life-history variation in juvenile Chinook salmon, Oncorhynchus tshawytscha (Walbaum). J. Fish Biol. 37:1-17.

1991. A review of local adaptation in Salmonidae, with particular reference to Pacific and Atlantic salmon. Aquaculture 98:185-207.

Taylor, E. B., C. J. Foote, and C. C. Wood. 1996. Molecular genetic evidence for parallel life-history evolution within a Pacific salmon (sockeye salmon and kokanee, Oncorhynchus nerka). Evolution 50:401-416.

Thompson, J. N. 1998. Rapid evolution as an ecological process. Trends. Ecol. Evol. 13:329-332.

Teel, D. J., G. B. Milner, G. A. Winans, and W. S. Grant. 2000. Genetic population structure and origin of life history types in Chinook salmon in British Columbia, Canada. Trans. Am. Fish. Soc. 129:194-209.

Utter, F., P. Aebersold, and G. Winans. 1987. Interpreting genetic variation detected by electrophoresis. Pp. 21-45 in N. Ryman and F. Utter, eds. Population genetics and fishery management. Univ. of Washington Press, Seattle, WA.

Utter, F., G. Milner, G. Stahl, and D. Teel. 1989. Genetic population structure of Chinook salmon, Oncorhynchus tshawytscha, in the Pacific northwest. Fish. Bull. (U.S.) 87:239-264.

Utter, F. M., D. W. Chapman, and A. R. Marshall. 1995. Genetic population structure and history of Chinook salmon of the Upper Columbia River. Am. Fish. Soc. Symp. 17:149-165.

Via, S., R. Gomulkiewicz, G. de Jong, S. M. Scheiner, C. D. Schlichting, and P. H. van Tienderen. 1995. Adaptive phenotypic plasticity: consensus and controversy. Trends Ecol. Evol. 10: 212-217.

Waples, R. S. 1988. Estimation of allele frequencies at isoloci. Genetics 118:371-384.

- 1991. Pacific salmon, Oncorhynchus spp., and the definition 
of "species", under the Endangered Species Act. Mar. Fish. Rev. 53(3):11-22.

. 1995. Evolutionarily significant units and the conservation of biological diversity under the Endangered Species Act. Am. Fish. Soc. Symp. 17:8-27.

2002. The effective size of fluctuating salmon populations. Genetics 161:783-791.

. 2004. Salmonid insight into effective population size. Pp. 295-314 in A. P. Hendry and S. C. Stearns, eds. Evolution illuminated: salmon and their relatives. Oxford Univ. Press, Oxford, U.K.

Waples, R. S., and D. J. Teel. 1990. Conservation genetics of Pacific salmon. I. Temporal changes in allele frequency. Conserv. Biol. 4:144-156.

Waples, R. S., O. W. Johnson, P. B. Aebersold, C. K. Shiflett, D. M. VanDoornik, D. J. Teel, and A. E. Cook. 1993. A genetic monitoring and evaluation program for supplemented populations of salmon and steelhead in the Snake River Basin. Annual Report of Research, Bonneville Power Administration, Portland, OR.

Waples, R. S., and 15 coauthors. 2001. Characterizing diversity in salmon from the Pacific Northwest. J. Fish Biol. 59(Suppl. A): $1-41$.

Washington Department of Fisheries, Washington Department of Wildlife, and Western Washington Treaty Indian Tribes. 1993. 1992 Washington State salmon and steelhead stock inventory (SASSI). Washington Department of Fish and Wildlife, Olympia, WA.

Weitkamp, L. A., T. C. Wainwright, G. J. Bryant, G. B. Milner, D. J. Teel, R. G. Kope, and R. S. Waples. 1995. Status review of coho salmon from Washington, Oregon, and California. U.S. Dept. Commerce, NOAA Tech. Memo. NMFS-NWFSC-24.

Welch, D., M. Trudel, J. Zamon, J. Morris, and M. Thiess. 2002. Potential interrelationships between patterns of migration and marine survival in Pacific salmon. N. Pac. Anad. Fish Comm. Tech. Rpt. 4:62-64.

Withler, F. C. 1982. Transplanting Pacific salmon. Canadian Tech. Rpt. Fisheries and Aquatic Sciences 1079. Dept. of Fisheries and Oceans, Vancouver, B.C.

Wood, C. C. 1995. Life history variation and population structure in sockeye salmon. Am. Fish. Soc. Symp. 17:195-216.

Wright, S. 1943. Isolation by distance. Genetics 28:114-138.

Corresponding Editor: J. Hey 
APPENDix 1

Samples used in the genetic analysis. Provinces are shown in Figure 1. $N$ is the total number of individuals sampled in the years indicated. Samples were taken from natural populations except those marked with an asterisk, which were taken from hatcheries.

\begin{tabular}{|c|c|c|c|c|c|c|}
\hline Province/Area & ID & Population & Run $^{1}$ & $N$ & Dates & Reference $^{2}$ \\
\hline \multicolumn{7}{|l|}{ A. Central Valley } \\
\hline \multirow[t]{2}{*}{ 1. San Joaquin } & 1 & Merced & $\mathrm{F}$ & 138 & $1998-1999$ & 10 \\
\hline & 2 & Tuolumne & $\mathrm{F}$ & 139 & 1998-1999 & 10 \\
\hline \multirow[t]{4}{*}{ 2. Sacramento } & 4 & Upper Sacramento & $\mathrm{W}(\mathrm{LF})$ & 160 & $1999-2000$ & 10 \\
\hline & 5 & Upper Sacramento & W & 198 & 1999 & 10 \\
\hline & 6 & Yuba & $\mathrm{S}$ & 32 & 2000 & 10 \\
\hline & 10 & Upper Sacramento & $\mathrm{F}$ & 188 & 1999 & 10 \\
\hline \multicolumn{7}{|l|}{ B. Northern California coast } \\
\hline & 11 & Mattole & $\mathrm{F}$ & 150 & 1984, 1987 & 5,10 \\
\hline & 12 & Middle Fork Eel & $\mathrm{F}(\mathrm{LF})$ & 95 & 1987 & 5 \\
\hline & 13 & North Fork Mad & $\mathrm{F}(\mathrm{LF})$ & 61 & 1987 & 5 \\
\hline & 14 & Redwood & $\mathrm{F}(\mathrm{LF})$ & 195 & 1987 & 5 \\
\hline \multirow{3}{*}{ 1. Klamath } & 18 & Salmon & SU & 98 & 1987 & 5 \\
\hline & 19 & Shasta & SU & 131 & 1984, 1987 & 5,10 \\
\hline & 20 & Bogus & SU & 128 & 1987 & 5 \\
\hline \multirow[t]{2}{*}{ 2. Coastal } & 21 & Winchuck & $\mathrm{F}$ & 170 & 1984,1995 & 10 \\
\hline & 22 & Chetco & $\mathrm{F}$ & 343 & $1981,1984,1988,1996$ & $2,5,10$ \\
\hline \multirow[t]{3}{*}{ 3. Rogue } & 23 & Cole Rivers* & $\mathrm{S}$ & 263 & $1981,1985,1995$ & 2,10 \\
\hline & 24 & Applegate & $\mathrm{F}$ & 181 & 1984,1988 & 5,10 \\
\hline & 25 & Rogue & $\mathrm{F}$ & 100 & 1988 & 5 \\
\hline \multicolumn{7}{|c|}{ D. Oregon and southern Washington coast } \\
\hline \multirow[t]{4}{*}{ 1. Oregon } & 26 & Rock Creek* & $\mathrm{S}$ & 300 & $1981,1985,1995$ & 2,10 \\
\hline & 27 & Trask & $\mathrm{S}$ & 300 & $1981,1985,1997$ & 2,10 \\
\hline & 28 & Elk & $\mathrm{F}$ & 100 & 1995 & 10 \\
\hline & 29 & Sixes & $\mathrm{F}$ & 268 & $1981,1983,1995$ & 2,10 \\
\hline \multicolumn{7}{|l|}{ E. Lower Columbia } \\
\hline 1. Lower Columbia & 39 & Cowlitz* & $\mathrm{S}$ & 152 & 1982,1987 & 2,9 \\
\hline & 40 & Kalama* & $\mathrm{S}$ & 159 & 1982,1987 & 2,9 \\
\hline & 41 & Lewis* & $\mathrm{S}$ & 135 & 1988 & 9 \\
\hline & 42 & Cowlitz* & $\mathrm{F}$ & 198 & $1981,1982,1988$ & 2,9 \\
\hline & 43 & Kalama* & $\mathrm{F}$ & 199 & $1982,1988-1989$ & 2,9 \\
\hline & 44 & Lewis & $\mathrm{F}(\mathrm{LF})$ & 120 & 1990 & 9 \\
\hline & 45 & Sandy & $\mathrm{F}(\mathrm{LF})$ & 140 & $1990-1992$ & 9 \\
\hline 2. Upper Willamette & 46 & McKenzie & $\mathrm{S}$ & 100 & 1997 & 10 \\
\hline & 47 & North Santiam & $\mathrm{S}$ & 99 & 1998 & 10 \\
\hline & 48 & North Fork Clackamas & $\mathrm{S}$ & 80 & 1997 & 10 \\
\hline F. Mid Columbia & & & & & & \\
\hline 1. Mainstem & 49 & Hanford Reach & $\mathrm{F}$ & 258 & 1982,1990 & 1,7 \\
\hline 2. Oregon Tributaries & 50 & Warm Springs & $\mathrm{S}$ & 80 & 1987 & 2 \\
\hline & 51 & North Fork John Day & $\mathrm{S}$ & 85 & 1990-1992 & 9 \\
\hline & 52 & Deschutes & $\mathrm{F}(\mathrm{SU} / \mathrm{F})$ & 179 & 1982, 1985, 1990-1992 & 2,9 \\
\hline 3. Yakima & 53 & Yakima & $\mathrm{S}$ & 261 & $1986,1989-1990$ & 4 \\
\hline & 54 & American & $\mathrm{S}$ & 226 & $1986,1989-1990$ & 4 \\
\hline & 55 & Yakima & $\mathrm{F}$ & 109 & 1990 & 4 \\
\hline G. Upper Columbia & & & & & & \\
\hline 1. Wenatchee & 56 & White & $\mathrm{S}$ & 137 & $1989,1991-1992$ & 9 \\
\hline
\end{tabular}


Appendix 1. Continued.

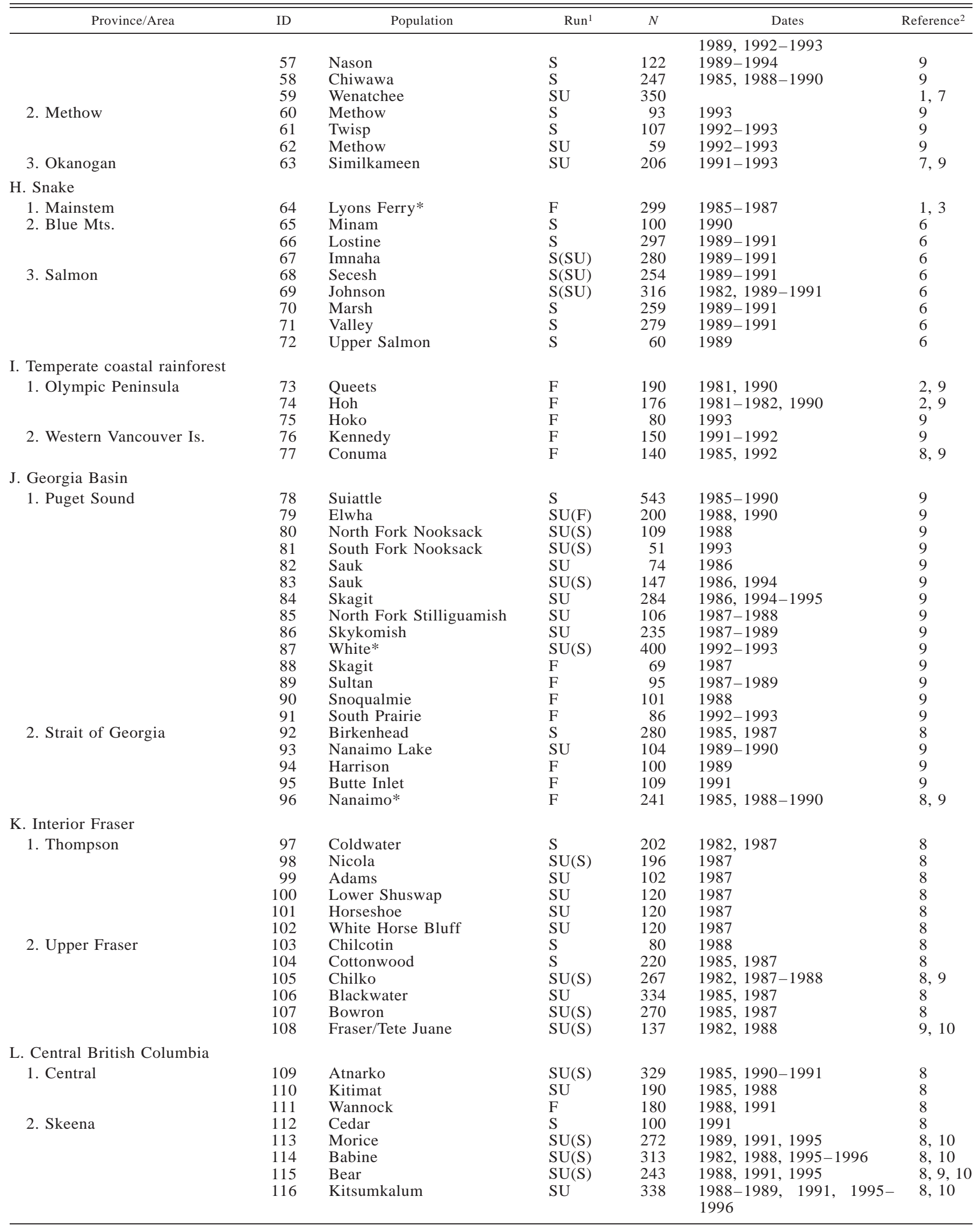


ApPEndix 1. Continued.

\begin{tabular}{|c|c|c|c|c|c|c|c|}
\hline & Province/Area & ID & Population & Run $^{1}$ & $N$ & Dates & Reference $^{2}$ \\
\hline 3. Nass & & $\begin{array}{l}117 \\
118\end{array}$ & $\begin{array}{l}\text { Cranberry } \\
\text { Damdochax }\end{array}$ & $\begin{array}{l}\text { SU(S) } \\
\text { SU(S) }\end{array}$ & $\begin{array}{l}93 \\
75\end{array}$ & $\begin{array}{l}1988-1989 \\
1988\end{array}$ & $\begin{array}{l}8 \\
8\end{array}$ \\
\hline
\end{tabular}

${ }^{1}$ Run indicates season of entry of adults into fresh water for their spawning migration: S, spring; SU, summer; F, fall; W, winter; LF, late fall (see Appendix 2 online for run-time data). For some populations, the seasonal run designation used here conflicts with the nominal run time typically used to characterize the population. In those cases, the nominal run time is shown in parentheses.

${ }^{2}$ Data sources: 1, Milner et al. 1986; 2, Utter et al. 1989; 3, Bugert et al. 1991; 4, Busack et al. 1991; 5, Bartley et al. 1992; 6, Waples et al. 1993; 7, Utter et al. 1995; 8, Teel et al. 2000; 9, A. R. Marshall, unpubl. data; 10, D. J. Teel, unpubl. data. 